\title{
Understory dynamics in cut and uncut western juniper woodlands
}

\author{
JON D. BATES, RICHARD F. MILLER, AND TONY J. SVEJCAR
}

\begin{abstract}
Authors are research associate, Oregon State University, Eastern Oregon Agricultural Research Center, Burns, Ore. 97720; professor, Rangeland Resources Department, Oregon State University, Eastern Oregon Agricultural Research Center, Burns, Ore.; and research leader, USDA-ARS, Eastern Oregon Agricultural Research Center, Burns, Ore. At the time of the research, the senior author was a research assistant, Rangeland Resources Department, Oregon State University, Eastern Oregon Agricultural Research Center.
\end{abstract}

\section{Abstract}

Expansion of western juniper (Juniperus occidentalis spp. occi dentalis Hook.) woodlands in the sagebrush steppe has the potential to change composition, structure, and productivity of understory vegetation. Cutting of western juniper woodland can potentially restore understory productivity and diversity. Understory responses were assessed after cutting a juniper woodland in southeastern Oregon in 1991. The experimental design was a randomized complete block with eight, 0.8 ha sized blocks and 2 treatments, cut and uncut woodland. Understory cover, density, diversity, biomass, and nitrogen $(N)$ status were compared between treatments after cutting. Plants were separated into 5 functional groups: bluegrass (Poa spp.), perennial bunchgrass, perennial forb, annual forb, and annual grass. Cutting of juniper reduced belowground interference for soil water and $\mathbf{N}$. Leaf water potentials were less negative $(P<0.01)$ and understory $N$ concentration and biomass $N$ were greater $(P<0.05)$ in the cut versus woodland treatment. Cutting of juniper trees was effective in increasing total understory biomass, cover, and diversity. In the second year post-cutting total understory biomass and $\mathbf{N}$ uptake were nearly 9 times greater in cut versus woodland treatments. Perennial plant basal cover was 3 times greater and plant diversity was 1.6 times greater in the cut versus woodland treatments. In the cut, perennial bunchgrass density increased by 1 plant $\mathrm{m}^{-2}$ in both duff and interspace zones and bluegrass increased by 3 plants $\mathrm{m}^{-2}$ in interspaces. Plant succession was dominated by plants present on the site prior to juniper cutting suggesting that pre-treatment floristics may be useful in predicting early successional understory response. Early plant dynamics on this site supports the multiple entrance point model of succession as perennial grasses and bluegrass made up the majority of total herbaceous biomass and cover.

Key Words: interference, water potential, nitrogen content, diversity, restoration, tree cutting.

Displacement of sagebrush steppe communities by the recent expansion of western juniper (Juniperus occidentalis spp. occi dentalis Hook.) woodlands has raised concerns over the effects of tree canopy development on plant community structure, composition, and diversity. Since the late 1800's western juniper has increased in density and spatial extent in central and eastern

This manuscript was submitted as Technical Paper 11,265 for the Oregon Agricultural Experiment Station.

Manuscript accepted 28 March 1999

\section{Resumen}

La expansión del "Western juniper" (Juniperus occidentalis spp. Occidentalis Hook) en las estepas de "Sagebrush" tiene el potencial de cambiar la composición, estructura y productividad de la vegetación herbácea. La tala de bosques de "Western juniper" puede potencialmente restaurar la productividad y diversidad de la vegetación herbácea. Se evaluó la repuesta de la vegetación herbácea después de cortar en 1991 un bosque de "Western juniper" en el sudeste de Oregon. El diseño experimental utilizado fue el de bloques completos al azar con 8 bloques de 0.8 ha y dos tratamientos, con corte y sin corte. Se comparó entre tratamientos la cobertura, densidad, diversidad, biomasa y el contenido de nitrógeno de la vegetación herbácea después de la tala. Las plantas fueron separadas en 5 grupos funcionales: "Bluegrass" (Poa. spp.), "Bunchgrass perenne", hierbas perennes, hierbas anuales y zacates anuales. El corte de "Western juniper" redujo la interferencia en el subsuelo del agua y el nitrógeno del suelo. Los potenciales de agua de las hojas fueron menos negativos $(\mathbf{p}<0.01)$ y la concentración de $\mathrm{N}$ de la biomasa de la vegetación herbácea fue mayor $(p<0.05)$ en el tratamiento con corte de "Western juniper". El corte de árboles de "Western juniper" fue efectivo para incrementar la biomasa total, cobertura y diversidad de la vegetación herbácea. En el segundo año después del corte, la biomasa de la vegetación herbácea y la absorción de nitrógeno fueron casi 9 veces mayores en el tratamiento con corte que en el tratamiento sin corte. La cobertura de plantas perennes fue 3 veces mayor $y$ la diversidad de plantas fue 1.6 veces mas en las áreas con corte que en las intactas. En las parcelas con corte, la densidad de "Bunchgrass" perenne se incremento a razón de 1 planta $\mathrm{m}^{-2}$ en los interespacios y el "Bluegrass" aumentó en 3 plantas $\mathbf{m}^{-2}$. La sucesión vegetal fue dominada por plantas que estaban presentes en el sitio antes de cortar el "juniper", sugiriendo que la composición florista pre-tratamiento puede ser útil para predecir la respuesta sucesional inicial de la vegetación herbácea. La dinámica inicial de las plantas en este sitio sostiene el modelo de sucesión de punto de entrada múltiple conforme los zacates perennes y el "bluegrass" constituyen la mayoría de la biomasa y cobertura total de la vegetación herbácea.

Oregon, northeastern California, and southwestern Idaho (Miller and Wigand 1994). Prior to Euro-American settlement, western juniper was largely confined to areas with shallow rocky soils underlain by fractured bedrock (Burkhardt and Tisdale 1969, Miller and Wigand 1994, Miller and Rose 1995). Recent juniper expansion has occurred in deeper more productive soils occupied 
by mountain big sagebrush [Artemisia tri dentata spp. vaseyana Nutt.] grasslands, riparian zones, and quaking aspen [Populus tremuloides Michx.] woodlands (Burkhardt and Tisdale 1969, Eddleman 1987, Miller and Rose 1995). Reduced fire frequency is the main causal factor attributed to the expansion of juniper (Burkhardt and Tisdale 1976, Evans and Young 1985). The decrease in fire frequency began in the late 1800 's with the suspension of fires set by Native-Americans (Miller and Wigand 1994). Reductions in fine fuel loads as a result of heavy livestock grazing at the turn of the century and additional fire suppression have further reduced fire frequency in shrub steppe communities (Burkhardt and Tisdale 1976, Miller and Wigand 1994). Succession to juniper-dominated communities is accompanied by reductions in understory productivity (West 1984, Vaitkus and Eddleman 1987), cover (Driscoll 1964), and diversity (Burkhardt and Tisdale 1969), increased site aridity (Angell and Miller 1994), and accelerated soil erosion (Buckhouse and Mattison 1980).

Juniper dominated communities are relatively stable and resistant to all but the most severe fire disturbances (Miller and Wigand 1994). Natural or prescribed fire is largely eliminated as a management tool for restoring understory vegetation in woodlands because of lack of fuels necessary to carry fires through juniper stands. Consequently, understory restoration in many juniper dominated communities is limited to mechanical treatments such as tree cutting or chaining.

Tree cutting is commonly used to restore understory productivity in areas occupied by western juniper. Cutting of trees in western juniper woodlands (Vaitkus and Eddleman 1987, Rose and Eddleman 1994) and Pinus monophylla Torr. \& Frem.-Juniperus osteosperma (Torr.) Little woodlands in Nevada (Everett and Sharrow 1985a) removes overstory interference and leads to greater understory biomass and cover. Nonetheless, there is insufficient quantitative and qualitative evidence documenting impacts of cutting in western juniper woodlands on plant community structure, composition, and diversity. It will be important to understand the effects of tree cutting in the juniper ecosystem because cutting is likely to increase in the near future as juniper may be used in a variety of wood products. There is concern that lack of a good ecological data base will hamper or misdirect decision making for understory restoration and commercial use of western juniper woodlands.
Understory dynamics after tree cutting in a western juniper woodland were assessed in this study. We hypothesized that cutting of juniper would reduce belowground interference for water and nitrogen, which would result in increased cover, biomass, density, and diversity of understory plants.

\section{Materials and Methods}

\section{Study Site}

The study site was on Steens Mountain in southeast Oregon $\left(118^{\circ} 36^{\prime} \mathrm{E}, 42^{\circ} 55^{\prime} \mathrm{N}\right)$. Elevation at the site is $1,525 \mathrm{~m}$. Aspect is west facing with a $22 \%$ slope. The site was dominated by an 80-year-old juniper woodland (Bates 1996). Full occupancy of the site by juniper was indicated by the limited leader growth on juniper trees, low herbaceous cover, and the majority of mountain big sagebrush shrubs being dead. Juniper canopy cover averaged $24 \%$ and tree density averaged 228 trees/ha. Bare ground accounted for $74 \%$ of the area and rill erosion was evident throughout the site. Basal cover of understory perennials averaged less than $2.3 \%$ across the site (Bates 1996). In the early 1900's this site was used as wintering grounds for domestic sheep. Since the late 1940's the site has been moderately grazed by cattle in the early spring.

The understory was dominated by Sandberg's bluegrass (Poa sandbergii Vasey). Sandberg's comprised about $75 \%$ of the total understory perennial plant basal cover. Other species characteristic of the site were bottlebrush squirreltail (Sitanion hystrix (Nutt.) Smith), bluebunch wheatgrass (Agropyron spicatum (Pursh) Scribn. \& Smith (syn. Pseudoroegenaria spicata (Pursh) A. Löve)), Thurber's needlegrass (Stipa thu beriana Piper), basalt milkvetch (Astragalus filipes Torr.), and pale alyssum (Alyssum alyssoides L.). Based on remnant plants, soils, elevation, and aspect, we judged the plant community prior to juniper encroachment to be a Mountain big sagebrush-Thurber's needlegrass association.

Climate in southeast Oregon is typically cool and moist during winter and spring periods, while summers are warm and dry. The majority of annual precipitation falls between November and late May. Water year (October 1-Sept. 30) precipitation at Malheur National Wildlife Refuge weather stations located $27 \mathrm{~km}$ southwest (elev. $1,300 \mathrm{~m})$ and $30 \mathrm{~km}$ northwest $(1,250 \mathrm{~m})$ of the site averaged $282 \mathrm{~mm}$ and $249 \mathrm{~mm}$, respectively, over the past 30 years.

Soils on the site are rocky, 40 to $50 \mathrm{~cm}$ deep, and clay loam in texture. Soils are underlain by a welded ash tuff of rhyolite/rhyodacite composition, which restricts root penetration. Soils were classified as clayey-skeletal, smectitic, frigid, Lithic Argixerolls.

\section{Experimental Design}

Experimental design was a randomized complete block with 8 blocks and 2 treatments, cut and uncut juniper woodland. Blocks were 0.8 ha in size and were selected for their similarities in soil type, slope, and aspect, and overstory/understory density and cover characteristics. Measurements of baseline vegetation characteristics were recorded prior to tree cutting in July 1991. Half of each block was cut with chainsaws in August 1991. All cut juniper trees were left in place. Leaving cut trees on site is a standard practice in eastern Oregon. Three small juniper trees $(<3 \mathrm{~m})$ were left in each cut block for measurement of leaf water potentials $\left(\Psi_{1}\right)$. Post-treatment measurements of understory characteristics, $\Psi_{1}$, and soil water content began in April 1992 and were concluded in September 1993. Livestock were excluded during the study.

\section{Understory Sampling Procedures}

Understory measurements were basal cover (perennial plants), canopy cover, density, diversity, biomass, and nitrogen (N) content. Understory plants were measured by species but are organized into 5 functional groups to simplify presentation of results (Table 1). The functional groups are: (1) bluegrass (Sandberg's bluegrass); (2) perennial grasses; (3) perennial forbs; (4) annual grasses; and (5) annual/biennial forbs. Sandberg's bluegrass is perennial but differs from the other bunchgrasses morphologically and phenologically. Sandberg's is of lower stature, with shallow roots, and grows and develops earlier in the spring than other bunchgrass species (Rickard and Vaughn 1988, Link et al. 1990).

Understory biomass was sampled at peak standing crop for perennial grass, bluegrass, perennial forb, and annual grass in 1992 and 1993. Biomass was sampled at 3-m intervals with $1-\mathrm{m}^{2}$ quadrats along two, 45-m randomly selected transects in cut and uncut woodland blocks. Vegetation was clipped to a 1-cm stubble height. Clipped herbage was dried at $60^{\circ} \mathrm{C}$ for 48 hours prior to weighing. In 1993, subsamples of each plant group were ground to pass a $0.1-\mathrm{mm}$ screen and ana- 
Table 1. Understory functional groups showing common species identified in cut and uncut western juniper woodland. Nomenclature of plant species follows Hitchcock and Cronquist (1973).

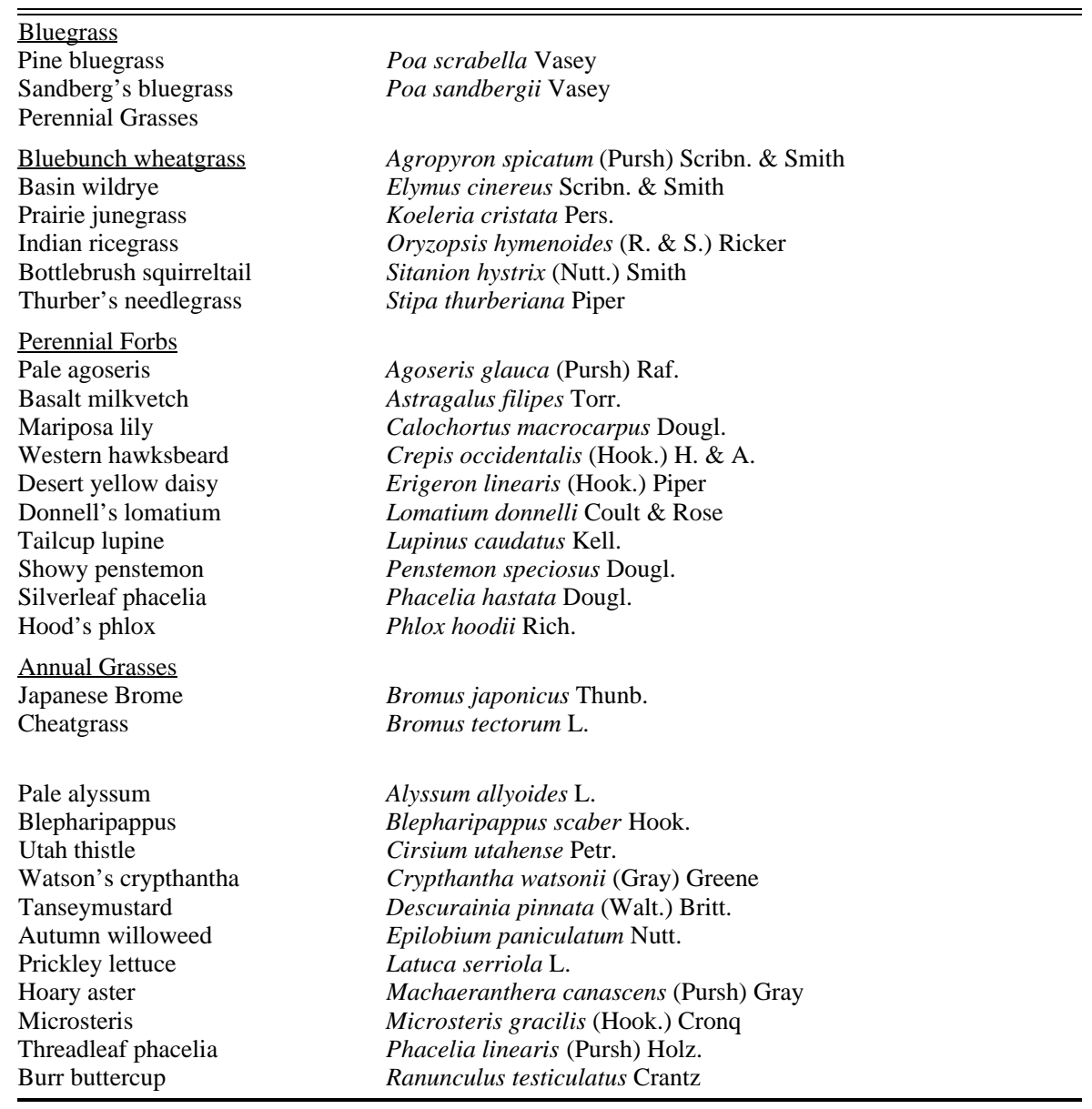

lyzed for $\mathrm{N}$ concentration using a PE 2400 II CHNS analyzer (Perkin-Elmer Corp. Norwalk, Connecticut $)^{1}$. Biomass $\mathrm{N}$ content was estimated by multiplying $\mathrm{N}$ concentration by understory biomass values.

Understory plant density was measured using $30.5 \times 61-\mathrm{cm}$ quadrats in duff and interspace zones. Duff zones were defined as: 1) areas beneath existing juniper canopies in uncut woodlands and 2) areas previously under juniper canopies in cut plots. Quadrats were placed in the outer third of the duff area. Interspace zones were defined as open areas not influenced by juniper litter. Subsampling for the interspace zone occurred approximately 3 $\mathrm{m}$ from the edge of duff zones. Density was measured in 4 cardinal directions around 12 randomly selected trees in each cut and woodland plot (48 quadrats per zone in each plot). Statistical analysis showed cardinal direction was not a significant factor in explaining treatment or zonal differences.

\footnotetext{
${ }^{1}$ Mention of trade names does not imply endorsement by Oregon State University or USDA-ARS.
}

Basal cover of perennial plants was measured along five, $30.5-\mathrm{m}$ line transects (Canfield 1941) in each cut and woodland plot in 1991, 1992, and 1993. Basal cover was separated into interspace and duff zones. Along transects ground cover provided by trees, litter zones (duff and cut trees), and canopy cover provided by herbaceous plants was estimated.

\section{Soil Water Availability and Plant Phenology}

Soil water availability was determined from gravimetric soil water content and leaf water potentials $\left(\Psi_{1}\right)$ of junipers during the 1992 and 1993 growing seasons (April-September). Soil water samples were collected the day preceding measurement of $\Psi_{1}$. Soil samples were collected at 2 depths, $0-20 \mathrm{~cm}$ and $20-40 \mathrm{~cm}$, in interspace soils of cut and woodland treatments. Five samples, randomly placed, were collected for each depth in each treatment plot. Soils water was determined gravimetrically after drying at $106^{\circ} \mathrm{C}$ for 48 hours. Soil water potentials and release curves $(-0.03$ to $-1.5 \mathrm{MPa})$ were developed using a pressure plate apparatus.

Leaf water potential of juniper was measured with a pressure chamber using methods described by Turner (1981). Predawn and midday $\Psi_{1}$ were collected every other week on 12 dates in 1992 and on 13 dates in 1993. Junipers were used because their root system explored the soil at all depths thus indicating the availability of water through the entire soil profile. Because soils were shallow $(\leq 45 \mathrm{~cm})$ we felt that juniper $\Psi_{1}$ would approximate herbaceous $\Psi_{1}$, at least during the spring growth period. Observation of understory phenology and growth characteristics (e.g. tillering, duration of the growth period) also served as indicators of soil water availability.

\section{Statistical Analysis}

Understory data were compared between treatments over time using ANOVA techniques for a randomized block design. Main effects for understory biomass and biomass $\mathrm{N}$ were year and treatment. Main effects for density and cover were year, treatment, and zone. Soil water content and leaf water potentials were analyzed using repeated measures ANOVA's for a randomized block design. Main effects for soil water content were treatment, soil depth, and time. All statistical analyses were performed using the Statistical Analysis System (SAS Institute 1988). Data was tested for normality using the SAS univariate procedure. Data not normally distributed were log transformed to stabilize variance. When interactions were significant means were separated using Fisher's protected LSD procedure. Statistical significance of all tests was assumed at $\mathrm{P}<0.05$.

Hill's (1973) N1 and N2 indices were used as indicators of plant diversity. Hill's $\mathrm{N} 2$ index is a measure of very abundant species and Hill's N1 index is a measure of abundant species. Hill's modified evenness ratio was used to compare relative abundances of species between zones (Ludwig and Reynolds 1988).

\section{Results and Discussion}

\section{Precutting Understory Characteristics}

Baseline measurements made before juniper cutting in 1991 indicated there were no differences in basal cover (Table 2) of herbaceous perennials or in understory plant density (Table 3 ), (except perennial forbs), between plots that were left as woodlands and plots selected to be cut. 
Table 2. Understory basal cover $(\%)$ means $( \pm$ SE) by year, zone, treatment and functional group. Column means sharing the same lower case letter are not significantly different $(\mathbf{P}>\mathbf{0 . 0 5})$.

\begin{tabular}{|c|c|c|c|c|c|c|c|}
\hline Parameter & Year & Zone & Treatment & $P O A$ & $P G$ & $P F$ & Total \\
\hline \multirow[t]{5}{*}{$\begin{array}{c}\text { Basal Cover } \\
(\%)\end{array}$} & 1991 & Interspace & $\begin{array}{l}\text { Cut } \\
\text { Woodland }\end{array}$ & $\begin{array}{l}1.1 \pm 0.2 \mathrm{a} \\
1.3 \pm 0.2 \mathrm{a}\end{array}$ & $\begin{array}{l}0.8 \pm 0.2 \mathrm{c} \\
0.7 \pm 0.1 \mathrm{bc}\end{array}$ & $\begin{array}{l}0.2 \pm 0.1 \\
0.3 \pm 0.1\end{array}$ & $\begin{array}{l}2.1 \pm 0.5 \mathrm{ab} \\
2.3 \pm 0.2 \mathrm{~b}\end{array}$ \\
\hline & & Duff & $\begin{array}{l}\text { Cut } \\
\text { Woodland }\end{array}$ & $\begin{array}{l}2.0 \pm 0.4 \mathrm{~b} \\
1.6 \pm 0.2 \mathrm{~b}\end{array}$ & $\begin{array}{l}0.6 \pm 0.1 b c \\
0.7 \pm 0.2 b c\end{array}$ & $\begin{array}{l}0.2 \pm 0.1 \\
0.3 \pm 0.1\end{array}$ & $\begin{array}{l}2.8 \pm 0.5 \mathrm{~b} \\
2.4 \pm 0.5 \mathrm{~b}\end{array}$ \\
\hline & 1992 & Interspace & $\begin{array}{l}\text { Cut } \\
\text { Woodland }\end{array}$ & $\begin{array}{l}1.0 \pm 0.2 \mathrm{a} \\
0.9 \pm 0.2 \mathrm{a}\end{array}$ & $\begin{array}{l}0.9 \pm 0.2 \mathrm{c} \\
0.4 \pm 0.1 \mathrm{ab}\end{array}$ & $\begin{array}{l}0.4 \pm 0.1 \\
0.2 \pm 0.1\end{array}$ & $\begin{array}{l}2.3 \pm 0.3 \mathrm{~b} \\
1.4 \pm 0.2 \mathrm{a}\end{array}$ \\
\hline & & Duff & $\begin{array}{l}\text { Cut } \\
\text { Woodland }\end{array}$ & $\begin{array}{l}1.7 \pm 0.5 \mathrm{~b} \\
1.4 \pm 0.2 \mathrm{~b}\end{array}$ & $\begin{array}{l}0.4 \pm 0.2 \mathrm{ab} \\
0.2 \pm 0.1 \mathrm{a}\end{array}$ & $\begin{array}{l}0.3 \pm 0.2 \\
0.1 \pm 0.0\end{array}$ & $\begin{array}{l}2.4 \pm 0.7 \mathrm{~b} \\
1.5 \pm 0.2 \mathrm{a}\end{array}$ \\
\hline & & Duff & $\begin{array}{l}\text { Cut } \\
\text { Woodland }\end{array}$ & $\begin{array}{l}2.8 \pm 0.4 \mathrm{c} \\
1.3 \pm 0.1 \mathrm{ab}\end{array}$ & $\begin{array}{l}1.9 \pm 0.5 \mathrm{~d} \\
0.1 \pm 0.1 \mathrm{a}\end{array}$ & $\begin{array}{l}0.2 \pm 0.1 \\
0.1 \pm 0.0\end{array}$ & $\begin{array}{l}4.8 \pm 0.9 \mathrm{c} \\
1.5 \pm 0.2 \mathrm{a}\end{array}$ \\
\hline
\end{tabular}

Perennial forb density was significantly less in cut interspaces than in other zones. Precutting analysis indicated density and cover of bluegrass was greater in duff zones than in interspaces $(\mathrm{P}<0.001)$. These zonal relationships for the functional groups did not change after tree cutting. Thus, post-cutting results for 1992 and 1993 will focus on treatment differences. Annual forb densities were probably under estimated in 1991. Annual forbs completed their growth phases by July when measurements were made, thus, many plants had deteriorated to the point where a complete count was no longer possible.

\section{Post-Cutting; Resource Availability}

Removal of juniper reduced belowground interference, thus increasing availability of soil water in 1992 and 1993. However, growing conditions and soil water availability differed markedly between years. The 1992 growing season was warmer and dryer than local and regional averages. Water year precipitation at nearby weather stations was $25 \%$ below average. Study site precipitation in the 1992 water year totaled $213 \mathrm{~mm}$, half of which was received late in the growing season in June and July. Despite a dry year, soil water content was significantly greater $(\mathrm{P}<0.01)$ at both depths in cut plots versus woodland plots throughout the growing season (April-September) (Fig. $1 \mathrm{~A}$ and $1 \mathrm{~B}$ ). As a result of greater available soil water, juniper predawn and midday $\mathrm{Yl}$ were less negative $(\mathrm{P}<0.001)$ in the cut versus woodland treatment (Figs. 2A and $2 \mathrm{~B}$ ). In both treatments $\Psi_{1}$ became more negative over time as soil water decreased during the growing season $(\mathrm{P}<0.001)$.

In 1993 eastern Oregon received record amounts of moisture. Precipitation at the Malheur Wildlife Refuge weather stations were $140 \%$ and $149 \%$ of long term averages. Precipitation on the study site totaled $418 \mathrm{~mm}$. Due to the wet spring, soil water content did not differ between treatments until late June (Fig 1A and 1B). Despite similar soil moisture conditions between March and June, juniper predawn and midday $\Psi_{1}$ were significantly less negative $(\mathrm{P}<0.001)$ in cut versus woodland plots (Figs. 2A and 2B). Differences in $\Psi_{1}$ between treatments increased after late
June as available soil water was depleted more rapidly in woodland plots.

Juniper interference with $\mathrm{N}$ uptake by the understory was evident in 1993. Nitrogen concentration in biomass was greater $(\mathrm{P}<0.05)$ in the cut versus woodland plots, with the exception of bluegrass (Table 4). The lower $\mathrm{N}$ concentration in bluegrass in the cut versus the woodland may have been due to a dilution effect (Mislevy and Everett 1981) resulting from greater bluegrass biomass in the cut treatment (Table 4). Total bluegrass biomass $\mathrm{N}$ was 5 times greater in cut versus the woodland plots. The combination of increased biomass production and greater $\mathrm{N}$ concentration in the other functional groups resulted in greater total aboveground understory $\mathrm{N}$ content in the cut plots (Table 4). We concluded that juniper interfered with understory $\mathrm{N}$ uptake in the woodlands because soil $\mathrm{N}$ availability and mineralization did not differ between the 2 treatments in 1993 (Bates 1996). Increased understory $\mathrm{N}$ content has also been measured after cutting pinyon-juniper woodlands in Nevada (Everett and Sharrow 1985b).

Table 3. Understory density (plants $\left.\mathrm{m}^{-2}\right)$ means $( \pm \mathrm{SE})$ by year, zone, treatment, and functional group. Column means sharing the same lower cowe letter are not significantly different $(\mathbf{P}<\mathbf{0 . 0 5})$.

\begin{tabular}{|c|c|c|c|c|c|c|c|c|}
\hline Parameter & Year & Zone & Treatment & Bluegrass & $\begin{array}{l}\text { Perennial } \\
\text { Grass }\end{array}$ & $\begin{array}{l}\text { Perennial } \\
\text { Forb }\end{array}$ & $\begin{array}{c}\text { Annual } \\
\text { Grass }\end{array}$ & $\begin{array}{c}\text { Annual } \\
\text { Forb }\end{array}$ \\
\hline \multirow[t]{4}{*}{$\begin{array}{l}\text { Density } \\
\left(\text { Plants } / \mathrm{m}^{2}\right)\end{array}$} & 1991 & Interspace & $\begin{array}{l}\text { Cut } \\
\text { Woodland }\end{array}$ & $\begin{array}{l}5.6 \pm 0.6 \mathrm{a} \\
6.1 \pm 0.6 \mathrm{ab}\end{array}$ & $\begin{array}{l}2.9 \pm 0.5 \mathrm{bc} \\
2.9 \pm 0.4 \mathrm{bc}\end{array}$ & $\begin{array}{l}0.4 \pm 0.1 \mathrm{a} \\
1.0 \pm 0.4 \mathrm{~b}\end{array}$ & $\begin{array}{l}0.3 \pm 0.2 \mathrm{a} \\
1.5 \pm 1.4 \mathrm{ab}\end{array}$ & $\begin{array}{l}6.2 \pm 5.2 \mathrm{a} \\
7.9 \pm 6.2 \mathrm{a}\end{array}$ \\
\hline & 1992 & Interspace & $\begin{array}{l}\text { Cut } \\
\text { Woodland }\end{array}$ & $\begin{array}{l}7.5 \pm 0.8 \mathrm{~b} \\
6.3 \pm 0.6 \mathrm{ab}\end{array}$ & $\begin{array}{l}3.2 \pm 0.3 \mathrm{c} \\
1.7 \pm 0.3 \mathrm{a}\end{array}$ & $\begin{array}{l}1.9 \pm 0.4 \mathrm{c} \\
2.1 \pm 0.4 \mathrm{c}\end{array}$ & $\begin{array}{l}0.4 \pm 0.1 \mathrm{a} \\
6.7 \pm 3.4 \mathrm{~d}\end{array}$ & $\begin{array}{r}85.6 \pm 16.4 \mathrm{~cd} \\
263.0 \pm 49.4 \mathrm{~d}\end{array}$ \\
\hline & 1993 & Interspace & $\begin{array}{l}\text { Cut } \\
\text { Woodland }\end{array}$ & $\begin{array}{l}8.4 \pm 0.6 \mathrm{~b} \\
6.9 \pm 0.7 \mathrm{ab}\end{array}$ & $\begin{array}{l}4.3 \pm 0.3 \mathrm{~d} \\
1.6 \pm 0.3 \mathrm{a}\end{array}$ & $\begin{array}{l}3.6 \pm 0.6 \mathrm{~d} \\
1.8 \pm 0.2 \mathrm{c}\end{array}$ & $\begin{array}{l}2.6 \pm 0.6 \mathrm{~d} \\
4.4 \pm 2.1 \mathrm{~cd}\end{array}$ & $\begin{array}{l}104.6 \pm 15.4 \mathrm{~d} \\
242.9 \pm 37.0 \mathrm{e}\end{array}$ \\
\hline & & Duff & $\begin{array}{l}\text { Cut } \\
\text { Woodland }\end{array}$ & $\begin{array}{l}15.4 \pm 1.6 \mathrm{c} \\
13.9 \pm 1.7 \mathrm{c}\end{array}$ & $\begin{array}{l}4.3 \pm 0.3 \mathrm{~d} \\
1.6 \pm 0.3 \mathrm{a}\end{array}$ & $\begin{array}{l}2.8 \pm 0.3 \mathrm{~d} \\
3.1 \pm 0.5 \mathrm{~d}\end{array}$ & $\begin{array}{r}16.7 \pm 3.6 \mathrm{e} \\
7.1 \pm 2.8 \mathrm{~d}\end{array}$ & $\begin{array}{c}79.3 \pm 5.4 \mathrm{c} \\
101.4 \pm 15.9 \mathrm{~d}\end{array}$ \\
\hline
\end{tabular}



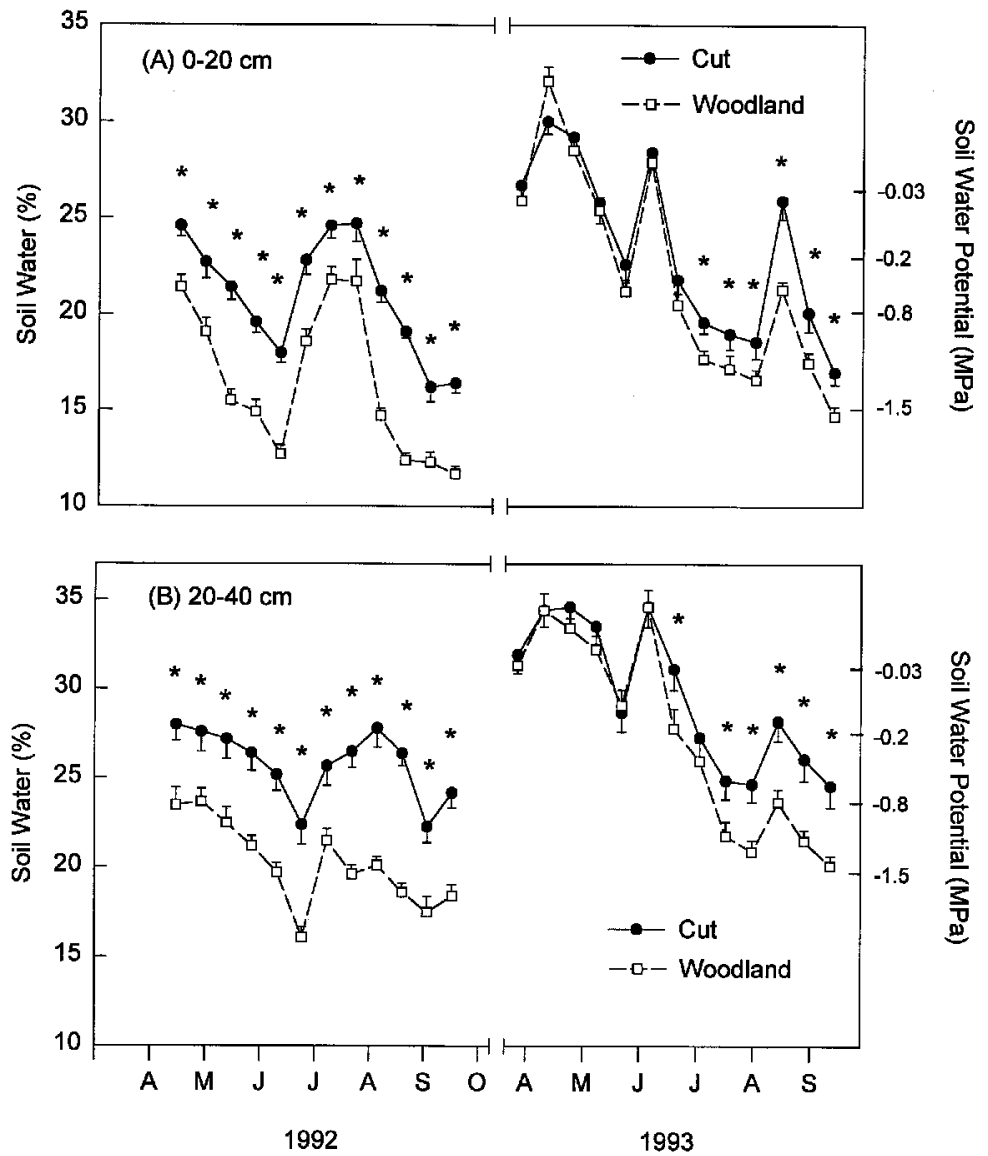

Fig 1. Volumetric soil water content and soil water potential in interspace soils from: (A) 0-20 cm; and (B) 20-40 cm. Data points are means + one standard error. Asterisks indicate significant treatment differences on that sampling date $(P<0.05)$.

\section{Post-Cutting; 1992 Understory Response}

Understory response to juniper cutting and the differing growth conditions in 1992 and 1993 produced both expected and unexpected results. In 1992, treatment differences for understory parameters were small and limited to perennial bunchgrass, perennial forb, and annual forb functional groups. Total understory biomass was 2 times greater $(\mathrm{P}<0.05)$ in the cut compared to the woodland treatment because of greater perennial bunchgrass and perennial forb production (Table 4). Basal cover (Table 2) and density (Table 3 ) of perennial bunchgrasses were also greater $(\mathrm{P}<0.05)$ in cut plots.

Differences between treatments for perennial bunchgrasses resulted from a decline $(\mathrm{P}<0.05)$ in bunchgrass cover (Table 2) and density (Table 3 ) in the woodlands between 1991 and 1992. The drier soil conditions in the woodlands (Figs. 1 and 2) was probably the main factor contributing to reductions in perennial bunchgrass cover and density. In cut plots bunchgrass density and basal cover showed no significant changes between
1991 and 1992 (Tables 2 and 3). Removal of juniper competition in the cut plots was therefore important in maintaining perennial grass cover and density in the dry year.

An unexpected result was the significantly higher densities $(\mathrm{P}<0.01)$ of annual forbs in the interspaces of the woodlands versus the cut (Table 3 ). This difference was a result of higher densities of pale alyssum, an early season annual in woodlands. Interspace density of pale alyssum averaged 218 plants $\mathrm{m}^{-2}$ in woodland plots versus only 72 plants $\mathrm{m}^{-2}$ in cut plots. We are unsure why interspace annual forb (i.e. pale alyssum) densities were lower in the cut versus woodland treatment considering that soil moisture availability was greater in the cut. Changes in micro-climate, which was not tested, could have negatively affected germination and establishment of pale alyssum, a winter annual, in cut treatment interspaces.

An important advantage to understory plants in the cut plots was their ability to respond to late growing season moisture in 1992. The site received about $90 \mathrm{~mm}$ of rain between late June and mid July.
Understory plants in the woodland treatment did not respond to the additional moisture and were dormant by early late June. In the cut plots we observed that perennial grasses and forbs, and annual forbs remained active into early September 1992. In July and August, perennial bunchgrasses and bluegrass tillered proficiently, and squirreltail and bluegrass produced a second set of reproductive structures. These basal tillers, initiated in summer 1992, were an important factor in increasing the potential for a significant perennial grass and bluegrass growth response in 1993.

\section{Post-Cutting; 1993 Understory Response}

Differences between treatments increased in magnitude in 1993. Total biomass production increased in both cut and woodland treatments (Table 4). However, total biomass increase was nearly 9 times greater in cut plots. Biomass of all the plant groups in the cut plots were greater $(\mathrm{P}<0.001)$ in 1993 than in 1992 and all were greater $(\mathrm{P}<0.001)$ in the cut versus the woodland treatment. In the woodlands, bluegrass was the only understory group with significantly more biomass in 1993 compared to 1992. Perennial grasses in woodlands showed no changes in biomass production (Table 4) and cover (Table 2) from 1992 to 1993, although soil moisture availability in the woodlands was similar to that in cut plots during spring 1993 (Figs. 1 and 2).

Total basal cover was 3 times greater in duff and interspace zones of cut plots compared to woodland plots (Table 2). Basal cover differences resulted from increased $(\mathrm{P}<0.01)$ perennial bunchgrass and bluegrass cover in cut plots between 1991 and 1993. Total ground cover was nearly twice as great $(\mathrm{P}<0.01)$ in the cut compared to the woodland treatment. Ground cover in the cut plots totaled $56 \%$ (juniper debris, 18\%; duff and other litter, $20 \%$; interspace herbaceous canopy cover, $18 \%$ ) compared to $29 \%$ in the woodland treatment (juniper trees and duff, $24.5 \%$; interspace herbaceous canopy cover, $4.5 \%$ ). The increase in herbaceous cover in the cut interspaces is important from a hydrologic standpoint. Erosion rates in semiarid systems are greatest in interspace zones (Wilcox and Breshears 1994). Research in New Mexico suggests that herbaceous ground cover is more effective at reducing erosion rates than is cover of woody vegetation (Wilcox and Breshears 1994). In the western juniper system, Buckhouse and Mattison (1980) measured greater soil ero- 


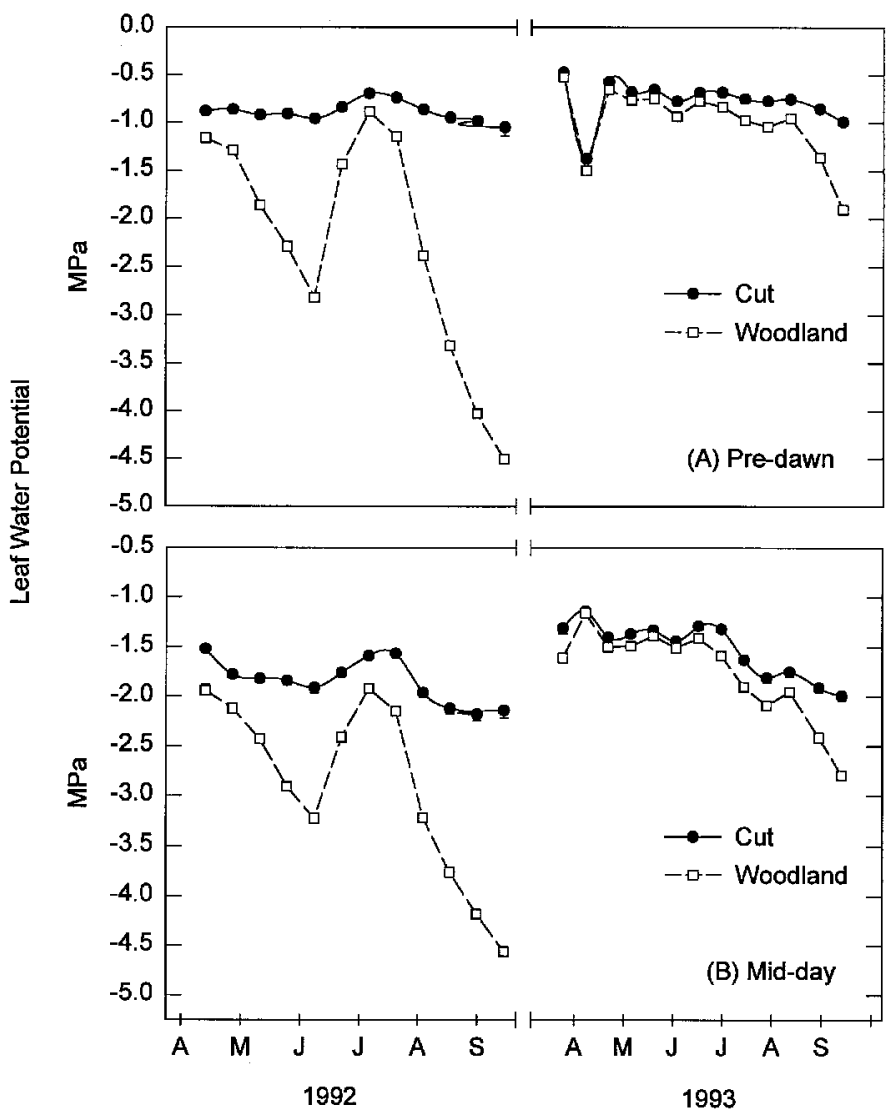

Fig 2. Juniper water potentials for: (A) pre-dawn and; (B) mid day measurements. Data points are means + one standard error. All data points show highly significant differences between treatments $(\mathbf{P}<0.001)$.

sion potential in woodland dominated sites than in sagebrush grasslands.

Densities of perennial bunchgrasses remained greater $(\mathrm{P}<0.05)$ in both duff and interspace zones of cut plots compared to woodland plots (Table 3 ). In cut plots perennial bunchgrass density increased by about 1 plant $\mathrm{m}^{-2}$ in both duff and interspace zones, and bluegrass increased by about 3 plants $\mathrm{m}^{-2}$ in interspaces from 1992. The majority of the increase in perennial grass density can be attributed to squirreltail (Bates et al. 1998). This suggest's squirreltail and bluegrass may, initially, colonize open sites more rapidly than other perennial grasses in this system.

Annual forb densities were greater in woodlands than cut plots in both duff and interspace locations in 1993 (Table 3). The lower annual forb densities in both locations of cut plots was a result of lower densities of pale alyssum compared to woodland plots (Bates 1996). As a result of higher spring moisture conditions annual and perennial forb densities increased significantly between 1992 and 1993 in woodland and cut duff locations, and cut interspace locations. Annual and perennial forbs in woodland interspaces did not respond with higher plant densities in the wet year.

In woodland plots the limited understory biomass response (Table 4) and lack of any cover changes (Table 2) in 1993 indicates that juniper interference of understory plants remains strong during wet years. We do not know how the understory on these shallow soil sites would respond to several additional years of above average soil moisture. Other resources, such as $\mathrm{N}$ may limit understory plant growth in high moisture years. Juniper appears to have interfered with understory $\mathrm{N}$ uptake (Table 4), which may have limited understory growth in woodlands in 1993 . Vaitkus and Eddleman (1987) also measured only small changes in understory biomass production in western juniper dominated communities when precipitation during a 2 -year period was double the 30 -year average. Additional research is needed to isolate competitive interactions between the understory and overstory in juniper woodlands in wet and dry years.

It has been suggested that junipers may restrict plant growth via the release of allelopathic compounds from litter (Jameson 1966, Gehring and Bragg 1992). Allelopathic effects should not be discounted, but seem unlikely given growth patterns of plants established in litter zones (duff and juniper debris areas) of cut plots. Individual plants that were established or became established in litter zones grew larger than their species counterparts in the interspace, particularly annual grasses and forbs (Bates et al. 1998).

Table 4. Means $( \pm$ SE) of understory biomass, $N$ concentration, and $N$ content parameters. Column means sharing the same lower case letter are not significantly different $(\mathbf{P}>\mathbf{0 . 0 5})$.

\begin{tabular}{|c|c|c|c|c|c|c|c|}
\hline Parameter & Year & TRT & Bluegrass & Bunchgrass & Perennial Forb & Annual Grass & Total Biomass \\
\hline \multirow[t]{2}{*}{$\begin{array}{l}\text { Biomass } \\
(\mathrm{kg} / \mathrm{ha})\end{array}$} & 1992 & $\begin{array}{l}\text { Cut } \\
\text { Woodland }\end{array}$ & $\begin{array}{l}12.2 \pm 1.1 \mathrm{a} \\
12.2 \pm 1.6 \mathrm{a}\end{array}$ & $\begin{array}{r}18.9 \pm 2.1 \mathrm{~b} \\
5.8 \pm 1.6 \mathrm{a}\end{array}$ & $\begin{array}{r}12.8 \pm 3.1 \mathrm{~b} \\
2.8 \pm 1.1 \mathrm{a}\end{array}$ & $\begin{array}{l}1.8 \pm 0.9 \mathrm{~b} \\
0.1 \pm 0.1 \mathrm{a}\end{array}$ & $\begin{array}{ll}45.7 \pm 3.2 & b \\
20.9 \pm 1.6 & a\end{array}$ \\
\hline & 1993 & $\begin{array}{l}\text { Cut } \\
\text { Woodland }\end{array}$ & $\begin{array}{l}141 . \pm 20.1 b \\
24.7 \pm 3.0 \quad c\end{array}$ & $\begin{array}{c}154.3 \pm 16.2 \mathrm{c} \\
7.8 \pm 1.6 \quad \mathrm{a}\end{array}$ & $\begin{array}{r}25.8 \pm 4.2 \mathrm{c} \\
4.5 \pm 1.0 \mathrm{a}\end{array}$ & $\begin{array}{l}7.8 \pm 2.3 \mathrm{c} \\
0.8 \pm 0.5 \mathrm{ab}\end{array}$ & $\begin{array}{c}329.0 \pm 35.2 \mathrm{c} \\
37.9 \pm 4.1 \quad \mathrm{~b}\end{array}$ \\
\hline $\begin{array}{l}\text { N Concentration } \\
(\%)\end{array}$ & 1993 & $\begin{array}{l}\text { Cut } \\
\text { Woodland }\end{array}$ & $\begin{array}{l}1.33 \pm 0.05 \mathrm{~g} \\
1.66 \pm 0.08 \mathrm{~h}\end{array}$ & $\begin{array}{l}2.13 \pm 0.05 \mathrm{~h} \\
1.56 \pm 0.07 \mathrm{~g}\end{array}$ & $\begin{array}{l}3.39 \pm 0.15 \mathrm{~h} \\
2.38 \pm 0.18 \mathrm{~g}\end{array}$ & $\begin{array}{l}2.10 \pm 0.11 \mathrm{~h} \\
1.60 \pm 0.16 \mathrm{~g}\end{array}$ & $\bar{\square}$ \\
\hline $\begin{array}{c}\text { Biomass N } \\
(\mathrm{kg} \mathrm{N} / \mathrm{ha})\end{array}$ & 1993 & $\begin{array}{l}\text { Cut } \\
\text { Woodland }\end{array}$ & $\begin{array}{l}1.88 \pm 0.07 \mathrm{z} \\
0.38 \pm 0.11 \mathrm{y}\end{array}$ & $\begin{array}{l}3.27 \pm 0.06 \mathrm{z} \\
0.12 \pm 0.04 \mathrm{y}\end{array}$ & $\begin{array}{l}0.87 \pm 0.12 \mathrm{z} \\
0.12 \pm 0.13 \mathrm{y}\end{array}$ & $\begin{array}{l}0.16 \pm 0.09 \mathrm{z} \\
0.01 \pm 0.12 \mathrm{y}\end{array}$ & $\begin{array}{l}6.19 \pm 0.21 \mathrm{z} \\
0.59 \pm 0.12 \mathrm{y}\end{array}$ \\
\hline
\end{tabular}


Table 5. Plant diversity (Hill's N1 and N2) indices and eveness ratio (Hill's modified evenness ratio) in duff and interspace locations for cut and woodland treatments. Column means sharing the same lower case letter are not significantly different $(\mathbf{P}>\mathbf{0 . 0 5})$. N1 ${ }^{1}$

\begin{tabular}{lccc}
\hline \hline $\begin{array}{l}\text { Year, Location } \\
\text { Treatment }\end{array}$ & $\mathrm{N} 1^{1}$ & $\mathrm{~N} 2^{2}$ & Evenness \\
\hline $\begin{array}{llll}1992 \\
\text { Interspace }\end{array}$ & & & \\
$\quad$ Cut & $5.0 \mathrm{~b}$ & $3.5 \mathrm{~b}$ & $0.63 \mathrm{ab}$ \\
$\quad$ Woodland & $3.2 \mathrm{a}$ & $2.5 \mathrm{a}$ & $0.68 \mathrm{~b}$ \\
$\quad$ Duff & & & \\
$\quad$ Cut & $7.0 \mathrm{~d}$ & $4.9 \mathrm{~d}$ & $0.65 \mathrm{ab}$ \\
$\quad$ Woodland & $3.6 \mathrm{a}$ & $2.5 \mathrm{a}$ & $0.58 \mathrm{a}$ \\
$\quad$ & & & \\
$\quad$ Interspace & & & \\
$\quad$ Cut & $5.9 \mathrm{c}$ & $4.0 \mathrm{c}$ & $0.61 \mathrm{a}$ \\
$\quad$ Woodland & $3.5 \mathrm{a}$ & $2.6 \mathrm{a}$ & $0.64 \mathrm{ab}$ \\
$\quad$ Duff & & & \\
$\quad$ Cut & $8.5 \mathrm{c}$ & $6.2 \mathrm{e}$ & $0.69 \mathrm{~b}$ \\
$\quad$ Woodland & $4.6 \mathrm{~b}$ & $3.1 \mathrm{ab}$ & $0.58 \mathrm{a}$ \\
\hline
\end{tabular}

$\mathrm{N} 1-$ is a measure of the number of abundant species.

${ }^{2} \mathrm{~N} 2-$ is a measure of very abundant species.

\section{Post-Cutting: Succession}

Understory response was largely determined by species present on the site prior to juniper cutting. About $70 \%$ of the species observed in 1992 and 1993 were present in the study area in 1991. Everett and Ward (1984) estimate that 60 to $80 \%$ of predisturbance species return within $1-5$ years after burning in pinyon-juniper woodlands. Thus, initial floristics of a site may be used to predict the general character of post-cutting understory response. We agree with Everett and Ward (1984) that making quantitative predictions of plant response are more difficult due to several unknowns, including status of seed bank reserves and post-treatment climate conditions.

Early secondary succession in the cut treatment was dominated by perennial bunchgrass and bluegrass groups in terms of biomass production and cover. In western juniper and other pinyon-juniper woodland studies, annuals, especially cheatgrass, have initially dominated after tree removal by cutting (Vaitkus and Eddleman 1987), chaining (Tausch and Tueller 1977), fire (Barney and
Frischknecht 1974, Quinsey 1984), and herbicide application (Evans and Young 1985). For many years it was assumed that succession in treated woodlands went through a standard successional progression beginning with several years of annual dominance followed by successive periods of grass and shrub primacy until trees re-occupied the site. More recently others have demonstrated that plant succession in treated pinyon-juniper woodlands is governed by multiple entrance points dependent on site characteristics and understory composition (Everett and Ward 1984, Everett 1987). Barney and Frischknecht (1974) and Quinsey (1984) reported that the annual stage may be bypassed in areas with fair perennial herbaceous cover prior to disturbance. Results from our study support the multiple entrance point model. In our study, pretreatment densities of perennial bunchgrass species (about 2-3 plants $\mathrm{m}^{-2}$ ) were sufficient for bunchgrasses to recover and largely dominate the understory component after cutting. Whether this density value is indicative of perennial grass response on other similar sites has not been adequately tested.

There was a compositional shift in biomass production toward later developing, deeper rooted perennial grasses and forbs after cutting. In cut plots, later developing (April-July), deeper rooted perennials (e.g. Thurber's needlegrass, squirreltail, bluebunch wheatgrass) became more dominant components of the understory while in woodland plots Sandberg's bluegrass made up the majority of understory biomass. For example, in 1993 perennial bunchgrasses and forbs represented $56 \%$ of total biomass in the cut treatment. In woodlands these same groups only accounted for $27 \%$ of total biomass. These results highlight the fact that resource availability on this site becomes limiting for later developing understory plants in established woodlands.

Biodiversity has become an important component in the management of rangelands. Diversity is important because species reductions or losses are perceived to negatively effect the quality and quanti- ty of ecosystem services (West 1993). On this site, dominance by juniper reduced understory diversity. Plant diversity was nearly 2 times greater $(\mathrm{P}<0.05)$ in cut plots in 1992 and 1993 compared to the woodlands (Table 5). The higher diversity indices (Hill's N1 and N2) in the cut treatment resulted from a greater variety of perennial and annual forb species (Table 6). A year, treatment, and zonal interaction indicated that diversity indices (N1 and N2) were greatest in cut plot duff zones in 1993 (Table 5). It is not clear what produced this interaction but it may result from differences in microsite characteristics influencing seed germination or plant establishment (e.g. nutrient availability, seed bank reserves, soil moisture conditions). In both treatments species numbers were greater in a wet compared to a dry year. The number of species increased by 11 in cut plots and by 9 in the woodland in 1993. The increase in the number of species resulted from emergence of native and introduced annual forbs and native perennial forbs. The high densities of pale alyssum relative to other species reduced species evenness in both treatments (Table 5). Species evenness tended to be lowest in woodland duff locations in both years compared to other treatment zones.

Because plant diversity quickly increased after cutting it does not appear that juniper dominance inhibited the recovery potential of this sites floristic diversity. Thus, it may take many years of woodland dominance before understory species are effectively removed from a site. It has been demonstrated that soil seed bank reserves and viability decline with woodland establishment and age (Koniak and Everett 1982). While our diversity values provide important information on the structure of site understory composition we do not have the ability to assess their importance or linkage to ecosystem function, an important component to evaluating range health.

\section{Management Considerations}

The results indicate restoration of woodland sites requires patience. Understory

Table 6. Herbaceous species numbers in clearcut and woodland treatments in 1992 and 1993 . Column means sharing the same lower case letter are not significantly different $(\mathbf{P}>0.05)$

\begin{tabular}{|c|c|c|c|c|c|c|c|}
\hline Year & Treatment & $\begin{array}{c}\text { Perennial } \\
\text { Grass }\end{array}$ & $\begin{array}{l}\text { Annual } \\
\text { Grass }\end{array}$ & 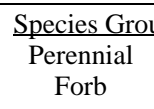 & $\begin{array}{c}\text { Native } \\
\text { Ann. Forb }\end{array}$ & $\begin{array}{l}\text { Non-native } \\
\text { Ann. Forb }\end{array}$ & $\begin{array}{c}\text { Total } \\
\text { Herbaceous }^{2}\end{array}$ \\
\hline 1992 & $\begin{array}{l}\text { Cut } \\
\text { Woodland }\end{array}$ & $\begin{array}{l}7.8 \pm 0.3 b \\
6.4 \pm 0.3 a\end{array}$ & $\begin{array}{l}1.8 \pm 0.2 \mathrm{~b} \\
1.1 \pm 0.1 \mathrm{a}\end{array}$ & $\begin{array}{l}8.9 \pm 0.6 \mathrm{c} \\
3.9 \pm 0.4 \mathrm{a}\end{array}$ & $\begin{array}{l}9.9 \pm 0.7 \mathrm{c} \\
2.5 \pm 0.3 \mathrm{a}\end{array}$ & $\begin{array}{l}3.5 \pm 0.2 \mathrm{~b} \\
2.0 \pm 0.0 \mathrm{a}\end{array}$ & $\begin{array}{l}34.3 \pm 1.5 \mathrm{c} \\
16.4 \pm 0.7 \mathrm{a}\end{array}$ \\
\hline 1993 & $\begin{array}{l}\text { Cut } \\
\text { Woodland }\end{array}$ & $\begin{array}{l}7.8 \pm 0.3 \mathrm{~b} \\
6.5 \pm 0.4 \mathrm{a}\end{array}$ & $\begin{array}{l}2.0 \pm 0.0 \mathrm{~b} \\
1.5 \pm 0.2 \mathrm{ab}\end{array}$ & $\begin{array}{r}15.0 \pm 0.6 \mathrm{~d} \\
6.6 \pm 0.7 \mathrm{~b}\end{array}$ & $\begin{array}{r}10.8 \pm 0.7 \mathrm{c} \\
7.5 \pm 0.7 \mathrm{~b}\end{array}$ & $\begin{array}{l}5.9 \pm 0.4 c \\
2.9 \pm 0.3 b\end{array}$ & $\begin{array}{l}45.6 \pm 2.0 \mathrm{~d} \\
25.4 \pm 0.7 \mathrm{~b}\end{array}$ \\
\hline
\end{tabular}


response was subtle and limited in the dry year, 1992, before responding dramatically in the wet year, 1993. Thus, it may take several years for understory species to respond to the removal of juniper, particularly during dry periods. However, the lack of a significant understory response the first year after cutting may not be unusual even in wet years. Studies in pinyon-juniper woodlands have shown delays of 1 to several years before the understory fully responds to removal of tree interference under favorable growing conditions (Barney and Frischknecht 1974, Tausch and Tueller 1977, Everett and Ward 1984, Vaitkus and Eddleman 1987). This is because it takes time for existing plants to grow larger and new plants to become established.

Cutting of trees on sites similar to the one used in this study will increase forage production and quality, improve watershed characteristics through increased ground cover, and increase plant diversity. However, variability in site characteristics (soils, aspect, elevation, understory composition) across the western juniper ecosystem will also influence understory response to juniper control. Additional research is required to develop models which assist land managers in predicting understory response and successional pathways after cutting trees across a variety of woodland dominated sites because not all sites will respond similarly. Because cutting is an expensive management alternative this treatment should only be applied to areas where a good understory response would be expected. Successional models would assist resource managers in targeting those areas where desirable understory vegetation may be successfully restored by juniper cutting.

\section{Literature Cited}

Angell, R.F. and R.F. Miller. 1994. Simulation of leaf conductance and transpiration in Juniperus occidentalis. Forest Sci. 40:5-17.

Barney, M.A. and N.S. Frischknecht. 1974. Vegetation changes following fire in the pinyon-juniper type of west-central Utah. J. Range Manage. 27:91-96.

Bates, J. 1996. Understory vegetation and nitrogen cycling following cutting of western juniper. Ph.D. Diss., Oregon State Univ., Corvallis, Ore.

Bates, J., R.F. Miller, and T.J. Svejcar. 1998. Understory patterns in cut western juniper (Juniperus occidentalis spp. occidentalis Hook.) Woodlands. Great Basin Nat. 58(4):363-375.
Buckhouse, J.C. and J.L. Mattison. 1980. Potential soil erosion of selected habitat types in the high desert region of central Oregon. J. Range Manage. 33:282-285.

Burkhardt, J.W. and E.W. Tisdale. 1969. Nature and successional status of western juniper vegetation in Idaho. J. Range Manage. 22:264-270.

Burkhardt, J.W. and E.W. Tisdale. 1976. Causes of juniper invasion in southwestern Idaho. Ecol. 57:472-484.

Canfield, R.H. 1941. Application of the line interception method in sampling range vegetation. J. Forestry 39:388-394.

Driscoll, R.S. 1964. Vegetation-soil units in the central Oregon juniper zone. Res. Pap. PNW-19. USDA-For. Serv. Pacific Northwest For. and Range Exp. Sta. Portland, Ore.

Eddleman L.E. 1987. Establishment and stand development of western juniper in central Oregon. p. 255-259. In: Proc. PinyonJuniper Conference, R.L. Everett (ed), Intermountain For. Range Res. Sta. USDAFor. Serv. Gen. Tech. Rep. INT-215. Ogden, Utah.

Evans R.A. and J.A. Young. 1985. Plant succession following control of western juniper (Juniperus occidentalis) with picloram. Weed Sci. 33:63-68.

Everett, R.L. 1987. Plant response to fire in the pinyon-juniper zone. p. 152-157. In: Proc. Pinyon-Juniper Conference, R.L. Everett (ed), Inter. For. Range Res. Sta., USDA-For. Serv. Gen. Tech. Rep. INT-215. Ogden, Utah.

Everett, R.L. and K.O. Ward. 1984. Early plant succession in pinyon-juniper controlled burns. Northwest Sci. 58:57-68.

Everett, R.L. and S.H. Sharrow. 1985a. Response of grass species to tree harvesting in singleleaf pinyon-Utah juniper stands. Inter. Res. Sta. USDA-For. Serv. Res. Pap. INT-334. Ogden, Utah.

Everett, R.L. and S.H. Sharrow. 1985b. Soil water and temperature in harvested and nonharvested pinyon-juniper stands. Inter. Res. Sta. USDA-For. Serv. Res. Pap. INT-342. Ogden, Utah.

Gehring, J.L. and T.B. Bragg. 1992. Changes in prairie vegetation under eastern red cedar (Juniperus virginiana L.) in an eastern Nebraska bluestem prairie. Amer. Midl. Nat. 128:209-217.

Hill, M.O. 1973. Diversity and evenness: a unifying notation and its consequences. Ecol. 54:427-432.

Hithcock, C.L. and A. Cronquist. 1973. Flora of the Pacific Northwest. Univ. of Washington Press. Seattle, Wash., USA.

Jameson, D.A. 1966. Pinyon-juniper litter reduces growth of blue grama. J. Range Manage. 19:214-217.

Koniak, S. and R.L. Everett. 1982. Seed reserves in soils of successional stages in pinyon-juniper woodlands. Amer. Midl. Nat. 108:295-303.

Link, S.O., G.W. Gee, and J.L. Downs. 1990. The effects of water stress on phenological and ecophysiological characteristics of cheat- grass and Sandberg's bluegrass. J. Range Manage. 43:506-512.

Ludwig J.A. and J.F. Reynolds. 1988. Statistical ecology: a primer on methods and computing. Wiley-Interscience Publ, John Wiley \& Sons, New York.

Miller, R.F. and J.R. Rose. 1995. Historic expansion of Juniperus occidentalis southeastern Oregon. Great Basin Nat. 55:37-45.

Miller, R.F. and P.E Wigand. 1994. Holocene changes in semiarid pinyon-juniper woodlands; responses to climate, fire, and human activities in the U.S. Great Basin. BioSci. 44:465-474.

Mislevy P. and P.H. Everett. 1981. Subtropical grass species response to different irrigation and harvest regimes. Agron. J. 73:601-604.

Quinsey, S.D. 1984. Fire and grazing effects in western juniper woodlands of central Oregon. M.S. Thesis. Univ. of Washington, Seattle, Wash.

Rickard, W.H. and B.E. Vaughn. 1988. Plant community characteristics and responses. p. 109-181. In: Shrub-steppe: balance and change in a semi-arid terrestrial ecosystem, W.H. Rickard, L.E. Rogers, B.E. Vaughn, and S.F. Liebetrau (eds.). Elsevior Sci. Publ. Co. Inc., New York, N.Y.

Rose, J.R. and L.E. Eddleman. 1994. Ponderosa pine and understory growth following western juniper removal. Northwest Sci. 68:79-85.

SAS Institute. 1988. User's Guide, Release 6.03 Edition. SAS Institute, Cary, N.C.

Tausch, R.J. and P.T. Tueller. 1977. Plant succession following chaining of pinyonjuniper woodlands in eastern Nevada. J. Range Manage. 30:44-49.

Turner, N.C. 1981. Techniques and experimental approaches for the measurement of plant water status. Plant \& Soil 58:339-415.

Vaitkus, M.R. and L.E. Eddleman. 1987. Composition and productivity of a western juniper understory and its response to canopy removal. p. 456-460. In: Proc. PinyonJuniper Conference, R.L. Everett (ed), Inter. For. Range Res. Sta. USDA-For. Serv. Gen. Tech. Rep. INT-215. Ogden, Utah.

West, N.E. 1984. Successional patterns and productivity of pinyon-juniper ecosystems. $\mathrm{p}$. 1301-1332. In: Developing strategies for range management. Westview Press, Boulder, Colo.

West, N.E. 1993. Biodiversity of rangelands. J. Range Manage. 46:2-13.

Wilcox, B.P. and D.D. Breshears. 1994. Hydrology and ecology of piñon-juniper woodlands: conceptual framework and field studies. p. 109-119. In: Desired Future Conditions for Piñon-Juniper Ecosystems. Rocky Mountain For. Range Exp. Sta. USDA-For. Serv. Gen Tech. Rep. INT-258. Fort Collins, Colo. 